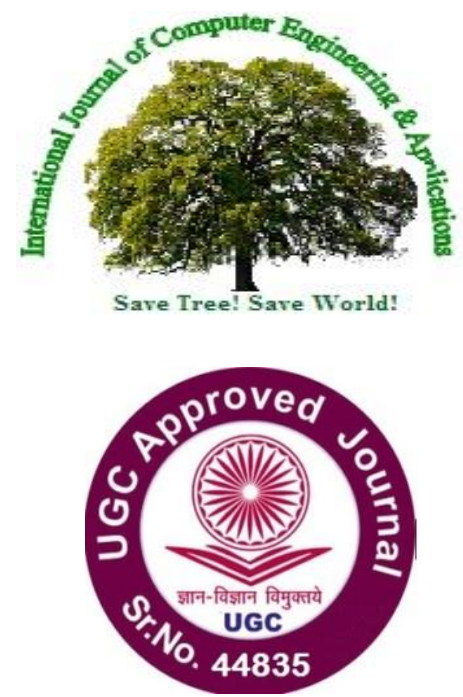

\title{
ONLINE EDUCATION IN PANDEMIC TIMES WITH SPECIFIC REFERENCE TO HIGHER EDUCATION: STUDENTS' PERSPECTIVES
}

\author{
Rohini Pattanshetti ${ }^{1}$, Shivali Patil ${ }^{2}$, Dr. Vaibhava Desai $^{3}$, Prof. Nripesh Nrip ${ }^{4}$ \\ ${ }^{1 \& 2}$ Student, ${ }^{3 \& 4}$ Assistant Professor, Bharati Vidyapeeth (Deemed to be University) Pune \\ Institute of Management Kolhapur Maharashtra India
}

\begin{abstract}
:
Education sector presently going through a crisis. The lockdown has restricted classroom teaching and students are completely relying on online content and remote learning features to study these days. The various platforms through which students are interacting with their teachers. Technology can be used as a resource in learning and can open new opportunities in the education sector. The online learning has transformed education. The purpose of this study was to conduct an online survey questions for students regarding student's perception about online classes and opinion about the online classes. The sample consisted of 40 students from colleges and universities in Kolhapur city. Online survey method was used for the purpose of data collection. The findings show that the following areas are important for student satisfaction with online classes, these areas are: quality and timely interaction between student and professor, technical support availability, structured online class modules, and accommodate conduction of online exam. But virtual classrooms will never replace the physical ones.
\end{abstract}

Keywords: Online classes, COVID-19, Survey, Technology, Students' Perspective

\section{[1] INTRODUCTION}

Online learning and classes are increasingly becoming part of the education system worldwide. Online channel has made education convenient and easily accessible by one and all. India has been one of the largest sectors in the world when it comes to higher education.

When it comes to the Indian educational system, face to face classroom approach has always been the most prominently used. Familiarity and ease of using offline methods and lack of requirement for online classes has been the major barriers for adoption of online learning.

However, in the wake of current COVID-19 pandemic situation conduction of online classes at college and university level has been made mandatory by the educational boards. COVID-19 has 
Online Education in Pandemic Times with Specific Reference to Higher Education: Students'

Perspectives

brought out a drastic change in the educational system not only in India but rather the entire world. Universities across India as well as around the globe have moved to the virtual classes suspending physical classrooms.

Online education in India is at an early stage of development. In India the government colleges and universities are still adapting. While technology makes things accessible and easier, it can also be limiting, especially in India, where many students face a challenge in terms of access to the internet. This in turn leads to issues with attendance and participation in online sessions, thereby making the adaptation of online learning a challenge. Meanwhile, face-to-face classroom setting can provide immediate feedback to faculty members and students about the quality of lesson, delivery, and experience. In classroom environment to gain a more detailed idea about the concepts is a major advantage compared to online learning.

Investigating and analyzing how online classes should be designed and arranged by taking into consideration the student's perspective. When it comes to the Indian educational setup, online classes are a newly introduced mode of teaching and not something that has been a part of regular classes.

How online classes are being perceived and experienced by students across different colleges and universities in India will help educational experts to understand and make modifications to suit the needs of students. Therefore, the significance of this research lies on exploring the students' perception toward online classes in comparison to face-to-face classes. The survey focused on students from colleges and universities in Kolhapur city.

Thus, the results of the survey which was done to understand how well this new method is being taken by students, what are the general problems faced by them while seeing online classes so as to help educational instructors and college and university managements to understand the modifications that can be brought to make online teaching more effective so that in future it can be integrated along with classroom teaching.

The responses from this survey will help to improve online mode of classes in order to provide a better learning experience for students.

\section{[2] METHODOLOGY}

For this study, we formed one short survey: for the students. The survey questions assessed the general perception and experience of students about online classes. The student's survey consisted of 24 questions regarding student's perception about online classes. Response choices consisted of pre-defined options of agree and disagree.

Due to the current COVID-19 situation, the survey was conducted through Online Mode. Students from Kolhapur colleges and universities which were conducting online classes were approached and asked to complete the survey.

The researchers covered Kolhapur city as far as geographical limitation of the area of the research study Questionnaire Circulated to 50 Students randomly selected from various colleges of the research area.

No of Higher Education Institutes in Kolhapur city

\begin{tabular}{|l|l|l|l|}
\hline Bachelors & Diploma & Masters & Total \\
\hline
\end{tabular}




\begin{tabular}{|l|l|l|l|}
\hline 21 & 07 & 09 & 37 \\
\hline
\end{tabular}

\begin{tabular}{|l|c|c|}
\hline \multicolumn{3}{|c|}{ Students Demographic Details(n=40) } \\
\hline Gender & Male & $56.8 \%$ \\
\cline { 2 - 3 } & Female & $43.2 \%$ \\
\hline \multirow{3}{*}{ Age } & $16-19$ & $13.5 \%$ \\
\cline { 2 - 3 } & $20-23$ & $86.5 \%$ \\
\hline \multirow{3}{*}{$\begin{array}{l}\text { Academic } \\
\text { Degree }\end{array}$} & Bachelor's & $35.1 \%$ \\
\cline { 2 - 3 } & Diploma & $6 \%$ \\
\cline { 2 - 3 } & Master & $24.3 \%$ \\
\cline { 2 - 3 } & Others & $35.1 \%$ \\
\hline
\end{tabular}

Table 1: Demographic Distribution of respondents

\section{[3] DATA ANALYSIS}

The main purpose of the study was to gather evaluative feedback from college and university students on their experience about online mode of teaching. A descriptive approach for data analysis was considered.

Response questions are coded, and categorized within each question to determine similar answer. Repetitive content of responses was identified. Finally, frequency counts of frequently occurring responses were tabulated and converted to percentages for reporting purposes. The section below describes the detailed findings of the survey.

\section{RESULTS}

The survey was done to get an understanding of the experience and perception of students about the recently introduced online mode of teaching. The survey Results are described below.

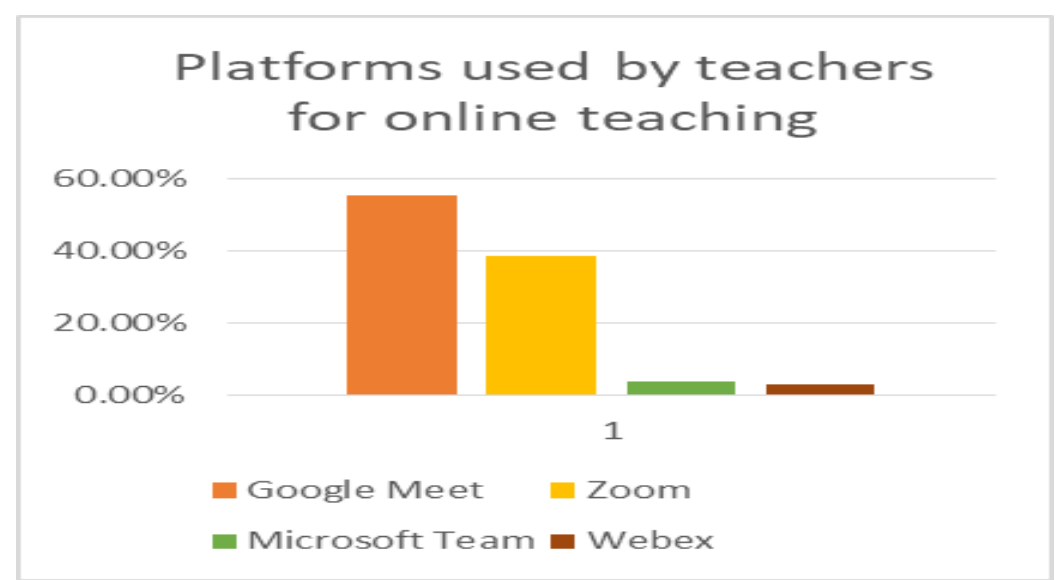

Graph 1: Shows the Platform frequently used by teachers for online teaching. 
Online Education in Pandemic Times with Specific Reference to Higher Education: Students'

Perspectives

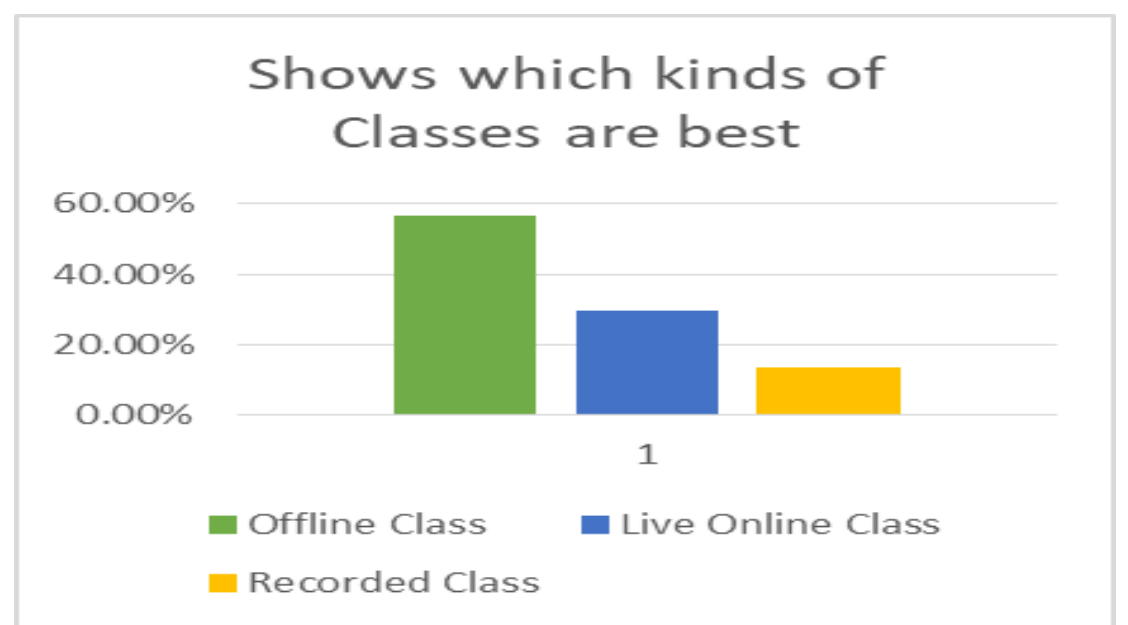

Graph 2: Respondent's opinions about the quality of Mode of Classes.

The results of the survey showed that $(56.8 \%)$ of the students reported that they preferred classroom teaching method more than online teaching mode. (29.7\%) preferred online classes and $13.5 \%$ student preferred Recorded classes.

\begin{tabular}{|c|c|c|}
\hline Survey Questions & Options & $\begin{array}{l}\text { Response } \\
(\%)\end{array}$ \\
\hline $\begin{array}{l}\text { On which platform study material are } \\
\text { provided? }\end{array}$ & $\begin{array}{l}\text { Google Classrom } \\
\text { WhatsApp } \\
\text { Telegram } \\
\text { Email }\end{array}$ & $\begin{array}{l}21.6 \% \\
59.5 \% \\
7 \% \\
13.5 \%\end{array}$ \\
\hline $\begin{array}{l}\text { Are you satisfied with the technology } \& \\
\text { software you are using for online } \\
\text { classes? }\end{array}$ & $\begin{array}{l}\text { Yes } \\
\text { No }\end{array}$ & $\begin{array}{l}64.9 \% \\
35.1 \%\end{array}$ \\
\hline $\begin{array}{l}\text { How helpful was the class material } \\
\text { provided to you? }\end{array}$ & $\begin{array}{l}\text { Extremely Helpful } \\
\text { Very Helpful } \\
\text { Somewhat Helpful } \\
\text { Not at all Helpful } \\
\end{array}$ & $\begin{array}{l}18.4 \% \\
39.5 \% \\
28.9 \% \\
13.2 \% \\
\end{array}$ \\
\hline $\begin{array}{l}\text { It is difficult to clarify doubts in online } \\
\text { classes. }\end{array}$ & $\begin{array}{l}\text { Agree } \\
\text { Disagree }\end{array}$ & $\begin{array}{l}76.3 \% \\
23.7 \%\end{array}$ \\
\hline $\begin{array}{l}\text { How much are you learning during } \\
\text { online classes compared to regular } \\
\text { class? }\end{array}$ & $\begin{array}{l}\text { Learning more } \\
\text { Learning less } \\
\text { Learning about the } \\
\text { same }\end{array}$ & $\begin{array}{c}27 \% \\
35.1 \% \\
37.8 \%\end{array}$ \\
\hline $\begin{array}{l}\text { Online classes are more effective than } \\
\text { classroom? }\end{array}$ & $\begin{array}{l}\text { Agree } \\
\text { Disagree }\end{array}$ & $\begin{array}{l}44.7 \% \\
55.3 \%\end{array}$ \\
\hline $\begin{array}{l}\text { There is a lack of interaction during } \\
\text { Online classes. }\end{array}$ & $\begin{array}{l}\text { Agree } \\
\text { Disagree }\end{array}$ & $\begin{array}{l}63.2 \% \\
36.8 \%\end{array}$ \\
\hline $\begin{array}{l}\text { Technical issues disrupt the flow of } \\
\text { online classes. }\end{array}$ & $\begin{array}{l}\text { Agree } \\
\text { Disagree }\end{array}$ & $\begin{array}{l}86.8 \% \\
13.2 \%\end{array}$ \\
\hline $\begin{array}{l}\text { Is your sending assignment regularly } \\
\text { checked? }\end{array}$ & $\begin{array}{l}\text { Regularly } \\
\text { Checked } \\
\text { Sometimes Checked } \\
\text { Sometime not } \\
\text { Checked } \\
\text { Not Checked }\end{array}$ & $\begin{array}{l}37.8 \% \\
32.4 \% \\
21.6 \% \\
8.1 \%\end{array}$ \\
\hline
\end{tabular}




\begin{tabular}{|l|l|l|}
\hline $\begin{array}{l}\text { Is your syllabus being completed in an } \\
\text { online classes? }\end{array}$ & Yes & $60.5 \%$ \\
\hline Online classes are save your time. & Yes & $39.5 \%$ \\
\hline Do you like to attend online exam? & No & $83.8 \%$ \\
& Yes & $16.2 \%$ \\
\hline Nature of online exam. & Objective & $81.6 \%$ \\
& Theoretical & $18.4 \%$ \\
\hline Do you follow the rules given for online & Yes & $81.6 \%$ \\
exam? & No & $18.4 \%$ \\
\hline Has the online exam affected your & Yes & $81.6 \%$ \\
career? & No & $18.4 \%$ \\
\hline \multicolumn{1}{|c|}{ Personal Factor in Online Classes } & $76.3 \%$ \\
\hline $\begin{array}{l}\text { I feel lazy \& disinterested during online } \\
\text { classes. }\end{array}$ & Agree & $23.7 \%$ \\
\hline Has the online class improved your & Disagree & $73.7 \%$ \\
technical skills? & Yes & $26.3 \%$ \\
\hline $\begin{array}{l}\text { I Feel more comfortable to participate } \\
\text { in online class discussion compared to } \\
\text { classroom. }\end{array}$ & No & $76.3 \%$ \\
\hline Have you done any other courses & Disagree & $23.7 \%$ \\
\hline besides online learning? & Yes & $52.6 \%$ \\
\hline $\begin{array}{l}\text { If your keep online classes } \\
\text { permanently! }\end{array}$ & No & $47.4 \%$ \\
\hline $\begin{array}{l}\text { Do you think the class provided good } \\
\text { value for money? }\end{array}$ & Agree & $62.2 \%$ \\
\hline & Disagree & $37.8 \%$ \\
\hline
\end{tabular}

Table 2: Survey Question on Student's perception about online classes

From table 2, it can be seen that when it came to online classes, students perceived the online classes to lack quality. Things such as technical issues, lack of structure, disturbance in the flow of classes, problems in clarifying doubts, lack of interest to attend the classes were some prominent factors reducing the effectiveness of online classes.

When asked about the problems generally faced by them during online classes, majority of them $(86.8 \%)$ reported technical issues like poor network connectivity, power cuts, poor audio and video quality, problems with the app, getting disconnected in between the classes and finding it hard to log in again as the main issues.

No structured learning environment makes it harder for the students to focus during the class.

(76.3\%) reported that online learning were difficult to understand. Especially, when in online classes, lack of concept clarity, no structured format. According to them too many subjects are scheduled on the same day which makes it difficult for them to stay alert and active.

(63.2\%) reported the online classes to be less interactive, no communication between students or with teachers and makes it harder to participate. Thus, the online classes they felt were less lively, lacked friendly atmosphere and social interaction.

Student's felts that when classes are taken through online, teachers do not teach effectively, they run through the syllabus and students feel they are being overloaded with information. 
Online Education in Pandemic Times with Specific Reference to Higher Education: Students'

Perspectives

(73.7\%) of them felt lack of interest to attend online classes. They felt that online classes make them less serious and they just attend the class for attendance and feel bored and lazy.

Some of the other issues reported were financial constraints (57.9\%). Students reported that the online classes increased their expense by recharging the data frequently, due to which they felt burdened, especially for students who come from financially fewer stable homes.

Come to the exam point of view (81.6\%) Students responded to attend online exams and around $(81 \%)$ of the Students preferred objective mode of examination rather than Theoretical examination.

But (76.3\%) Students responded that the online exam will affected their career.

The positive aspect of online classes majority found it to be time saving (83.7\%), as it could be done from the comfort of the home which save time to travel and commute, don't have to rush to reach college. Other positive things reported were: faster completion of syllabus, recording of classes helped in referring to it later. The recorded classes could be watched again and again until the concept is clear. Classes can be attended anywhere, anytime thus, giving flexibility.

In online learning $(76.3 \%)$ students responded that they improved their technical skills and also done other courses besides online classes.

The result of this study indicates that face- to- face learning was perceived more positively than online learning in term of social presence, interaction, satisfaction and overall quality. Even though online classes were reported to be convenient in term of saving time, still students perceived it to be less effective and structured when compared to classroom mode of learning.

This study indicates that technical issues were found to be the most influential factor when it came to satisfaction with online classes. The results found here will thus allow college administrators to determine how technical support can be expanded and to reach all students, thereby, improving their experience and making the classes more effective.

\section{[4] CONCLUSION}

Students' comfort with online class design, structure, level of interaction between students and faculty, the quality and amount of class content, technical support, and overall experience with online class delivery impact the overall teaching and learning experience and determines the ultimate success or failure of online mode of education.

Thus, awareness needs to be increased focusing on the convenience and accessibility aspect in order to increase the adoption of online learning by students.

Improving the quality of online classes with the help of various service providers, along with support from different colleges and universities can help in making online mode of education more effective and easily acceptable.

Establishing a structured and user-friendly environment for online mode of education, one that is accessible for all without putting financial burden on students.

The information can throw light on the general issues faced by students during online classes. Online mode of higher education is still in the early stage of development in India, therefore having clarity about the problems experienced and the expectations of students will help to plan out effective and structured strategies for taking online classes.

This study indicate that student's perceptions are valuable to educational institutions planning to adapt online mode of teaching in the future. However, this survey has its limitations. The small sample may not be completely representative of the majority of students taking online classes. 


\section{REFERENCES}

[1] Shivangi Dhawan (2020).Online learning: A Panacea in the Time of COVID-19 Crisis. Journal of Educational Technology System 49(1), 5-22.

[2] D. Nambiar (2020). The impact of online learning during COVID19: students' and teachers' perspective. International Journal of Indian Psychology, 8(2), 783-793.

[3] Alsoud, A.R.; Harasis, A.A. The Impact of COVID-19 Pandemic on Student's E-Learning Experience in Jordan. J. Theor. Appl. Electron. Commer. Res. 2021, 16, 1404-1414.

[4] Girish K.Jha (2021).Student's Perception and preference for online education in India during COVID-19 pandemic.

[5] Claudiu Coman (2020). Online Teaching and Learning in Higher Education during Coronavirus Pandemic: Students Perspective. 12(24).

[6] Keengwe, J., \& Kidd, T. T. (2010). Towards best practices in online learning and teaching in higher education. MERLOT Journal of Online Learning and Teaching, 6(2), 533-541.

[7] Jones I and Blankenship D (2017). Students' perception of online courses. Journal of Research in Higher Education. vol. 32

[8] O'Malley, J., \& McGraw, H. (1999). Students perceptions of distance learning, online learning and the traditional classroom. Online Journal of Distance Learning Administration, 2(4)

[9] Ali, W. Online and Remote Learning in Higher Education Institutes: A Necessity in light of COVID-19 Pandemic. High. Educ. Stud. 2020, 10, 16-25. [CrossRef]

[10] Abou El-Seoud, S.; Seddiek, N.; Taj-Eddin, I.; Ghenghesh, P.; Nosseir, A.; El-Khouly, M. ELearning and Students' Motivation: A Research Study on the Effect of E-Learning on Higher Education. Int. J. Emerg. Technol. Learn. 2014, 9, 689-695. [CrossRef]

[11] Dhawan, S. Online Learning: A Panacea in the Time of COVID-19 Crisis. J. Educ. Technol. Syst. 2020, 49, 5-22. [CrossRef]

[12] Marinoni, G.; Van't Land, H.; Jensen, T. The Impact of COVID-19 on Higher Education around the World. International Association of Universities. Available online: https://www.iauaiu.net/IMG/pdf/iau_covid19_and_he_survey_report_final_may_2020.pdf (accessed on 14 August 2020).

\section{Author[s] brief Introduction}

1. Rohini Pattanshetti - Student of MCA-II (Sem- III), Bharati Vidyapeeth (Deemed to be University) Institute of Management Kolhapur. Mail: Rohinipattanshetti2017@gmail.com

2. Shivali Patil - Student of MCA-II (Sem- III), Bharati Vidyapeeth (Deemed to be University) Institute of Management Kolhapur. Mail: shivalipatil98@gmail.com

3. Dr. Vaibhava Desai - Assistant Professor, Dept. of Management Studies, Bharati Vidyapeeth (Deemed to be University) Institute of Management Kolhapur. Mail:

vaibhava.desai@bharatividyapeeth.edu

4. Prof. Nripesh Nrip - Assistant Professor, Dept. of Computer Application, Bharati Vidyapeeth (Deemed to be University) Institute of Management Kolhapur. 